\title{
Measuring Bone Mineral Content and Soft Tissue Mass in Living the Cynomolgus Monkey
}

\author{
Hayato NARITA, Fumio OHKUBO, Takashi YOSHIDA*, \\ Fumiaki $\mathrm{CHO}^{*}$, and Yasuhiro YOSHIKAWA* \\ The Corporation for Production and Research of Laboratory Primates and ${ }^{*} T$ Tsukuba \\ Primate Center for Medical Science, The National Institute of Health, 1 \\ Hachimandai, Tsukuba-shi, Ibaraki 305, Japan
}

(Received 26 October 1993/Accepted 11 January 1994)

\begin{abstract}
Bone mineral content and soft tissue (lean and fat) mass in living female cynomolgus monkeys were successfully measured with a dual-energy X-ray absorptiometry (DEXA ; DPX- $\alpha$, LUNARE, USA). Measurements were performed using a restraining bed made of forming polystyrol with $5 \mathrm{~cm}$ thickness to support the animal in a supine position. Accuracy of measurements was checked by using a dummy consisted by various combinations of lean, lard and ribs. The results confirmed that this system is able to measure each consitituent exactly. The percentage of fat in the soft tissue is seemed to be better index of obesity in this primate species when compared with other obesity markers such as body weight and morphometry. KEY WORDS : cynomolgus monkey, dual energy X-ray absorptiometry, obesity
\end{abstract}

\section{カニクイザルの骨量・軟部組織量の生体計測}

成田勇人 ・大久保文雄・吉田高志*

長 文昭*・吉川泰弘*

社団法人予防衛生協会

*国立予防衛生研究所筑波医学実験用霊長類センター

筑波霊長類センターでは, 実験用カニクイザルの継 代繁殖・育成をおこなっている。 SPF 動物の作出を基 本においているために, 飼育は個別ケージを用いて行 つている。野生ザルおよび放飼場のサルに比べて相対 的な運動量の減少と過食傾向にあるため，カニクイザ ルの育成をおこなうにあたって, 肥満個体の出現をど のように防ぐか，ということは重要な課題のひとつで ある [7]。育成カニクイザルの適切な飼育管理をおこ なうにあたって，我々は，これまで体重 [8] や，生 体計測值 $[4,6]$ を成長と肥満の指標として用いてき
た。さらに，固型飼料の給餌量を制限して，その成長 へおよぼす影響等について検討を加えてきた $[5,9]$ 。 しかし，カニクイザルの肥満状態を適確に把握するた めの指標として充分に満足されるものは，今のところ 見当らない。

最近, 我々は二波長 X線骨密度測定装置 (DEXA) がサル類の腰椎骨の測定に有用であることを指摘した [1]。骨量を測定するためにDEXA ではX 線源とし てX線管を用いている。他方, 測定原理はDEXA と 全く同じで，ただX線源として ${ }^{153} \mathrm{Gd}$ を用いる二光子 


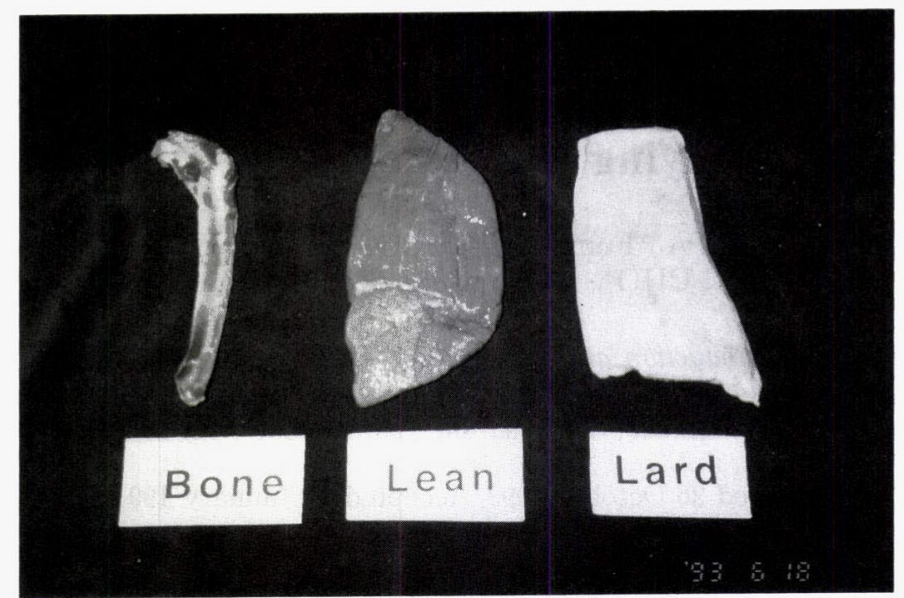

Fig. 1. Accuracy of measurements was confirmed by using dummies consisted by bovine lean, porcine ribs and lard.

密度測定装置（DPA）もまた骨量測定などに用いら れている。最近, DPAによって, 体脂肪量 [3] や軟 部組織量 [2] の測定がヒトで可能であることが報告 されている。そこで, カニクイザルの肥満度の指標を 得るために我々は, DEXA を骨密度測定装置として のみならず, カニクイザルの全身画像の解析装置とし て用い, 全身の骨量, 軟部組織量 (脂肪量・赤身肉 量）の生体計測に適用することを試みると同時に, 力 ニクイザルでの測定方法および測定值の信頼性につい ても併せて検討したので,ここに報告する。

供試動物：測定に用いた個体は, 当センターで誕生し た体重が約 $1 \mathrm{~kg}$ から $7 \mathrm{~kg}$ の雌のカニクイザル49頭 であり, 年齢は約 1 歳齢から 14 歳齢にわたるものであ る。すべて実験室内で 1 日あたり 14 時間の照明, 温度 $25 \pm 2{ }^{\circ} \mathrm{C}$, 湿度 $60 \pm 10 \%$, 換気 12 回/時で飼育した。 飼料は, 午前中にリンゴ, ミカンを各 $100 \mathrm{~g}$, 午後に サル用固型飼料（オリエンタル酵母社， AS 型）を70 $\mathrm{g}$ 給慨した。測定は, 塩酸ケタミン (ケタラール50, 三共) と, キシラジン (セラクタール, バイエル)を $2: 1$ に混合し, その混液を $0.3 \mathrm{~m} \ell / \mathrm{kg}$ 体重で筋肉 内投与し麻酔下でおこなった。

測定：測定には DPX- $\alpha$ (Lunar 社製, U. S. A.) を用いた。測定にあたっては, ヒトでの測定時に使用 するマットをはずし, 代りに $5 \mathrm{~cm}$ の厚さの発泡スチ ロール製の板 $(\mathrm{W} 30 \times \mathrm{L} 150 \mathrm{~cm})$ を動物の下に敷い た。この板には, 着脱式の布製テープを接着し, 動物 を仰向けに保定できるようにした。さらに, 動物の保
定時に, 直径約 $8 \mathrm{~cm}$, 長さ約 $15 \mathrm{~cm}$ の空気枕 4 個を 用いて動物の身体を真っすぐにさせた。

測定の信頼性：測定の信頼性を確認するために, ウシ の赤身肉（股肉） $6 \mathrm{~kg}$, ブ夕の脂身 $1 \mathrm{~kg}$ および肋 骨1.7kg を用い (Fig. 1), それぞれの量を変えなが ら測定し, 実重量と測定值との関係を解析した。

解析：解析は, 全身モードで小児用プログラムを用い ておこなった。

本研究に用いた解析プログラムは小児用として開発 されたものであり，体重が $3 \mathrm{~kg}$ 以下の小動物の測定 を想定したものでは無い。ヒトでの測定時に使用する ウレタン製マットは, 体重 $3 \mathrm{~kg}$ 以下のカニクイザル には適合せず, 推定体重が実体重より20３0\%程度大 きく測定されてしまう。そこで, マットをカニクイザ ルでの測定に合うように改良し, 厚さ $5 \mathrm{~cm}$ の発泡ス チロール製の板を使用した。さらに，カニクイザルの 全身をX線が走査し終るまでには15２0分の時間を必 要とするため, 測定に影響をおよぼさない空気枕と着 脱式布テープによって動物を保定した。

これらの改良によって, 体重が $3 \mathrm{~kg}$ 以下の動物で も測定が可能か否かを検討する目的で, 赤身肉・脂 身・肋骨を用いたダミーを使用した。これら 3 部分 を, 適宣, 増減して測定を行なったところ実重量で約 $0.5 \mathrm{~kg}$ から $8 \mathrm{~kg}$ 以上の範囲で直線性が確認され, 実 重量と, 測定で得られた骨量 (BMC) と軟部組織量 の和を推定重量とした時の差は, 重量を測定した体重 計の誤差の範囲（数十 $\mathrm{g}$ ) 以内にとどまった $(\mathrm{P}<$ 

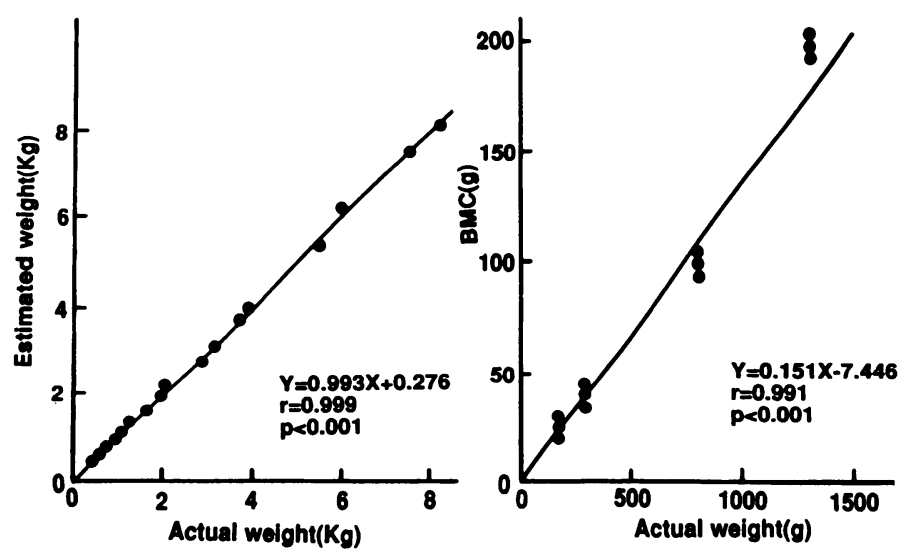

Fig. 2. The relationship between actual weight of dummies and estimated weight by a dual energy $\mathrm{X}$-ray absorptiometry (DEXA, left) and the relationship between actual rib weight of dummies and bone mineral content (BMC) measured (right). Correlation coefficient $(r)$ and statistical significance $(p)$ are indicated in the figure.

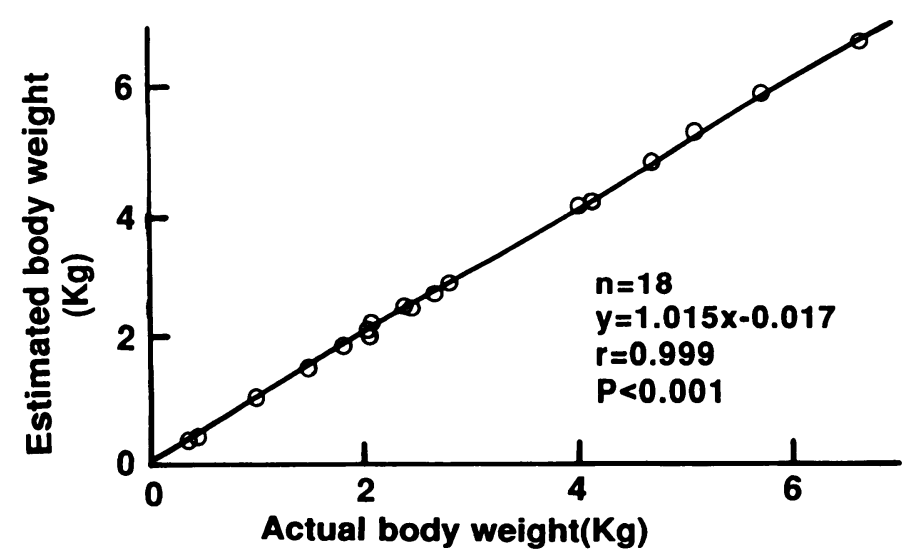

Fig. 3. The relationship between actual body weight of female cynomolgus monkeys weighing $0.5 \mathrm{~kg}$ to $7 \mathrm{~kg}$ and estimated body weight by a DEXA. Correlation coefficient( $r)$ and statistical significance $(p)$ are indicated in the figure.

0.001， r =0.999)。さらに, ダミーに含めた胁骨の 添付重量に比例した BMCの測定值の変化が, BMC 值として25 g から $200 \mathrm{~g}$ の範囲で確認することができ た (Fig. 2)。本研究に用いた胁骨のうち $13.6 \pm 1.5$ \%が BMCであるという成績が得られた。以上の成績 から，BMC ならびに軟部組織量の本装置による測定 值は，充分に信頼できるものと判断された。本検討に 用いた赤身肉にも胁骨にも，脂肪が含まれている。そ のために軟部組織量に占める脂肪の割合 (\% Fat) の
測定值については最終的な確認はとれなかったもの の, 本装置を使用する, という条件で相対值として比 較をおこなうことは可能であろう。さらに，実際に力 ニクイザルを測定し, 得られた軟部組織量と BMC と の和を推定体重とし, 実体重との関係を見たところ, その相関は高度に有意であり, カニクイザルの体重 $500 \mathrm{~g}$ から $7 \mathrm{~kg}$ まで直線関係が得られた（Fig. 3 )。

カニクイザルの体重と各測定值との関係を見るため に各種の関数式を適合させたところ, 体重と赤身肉量 


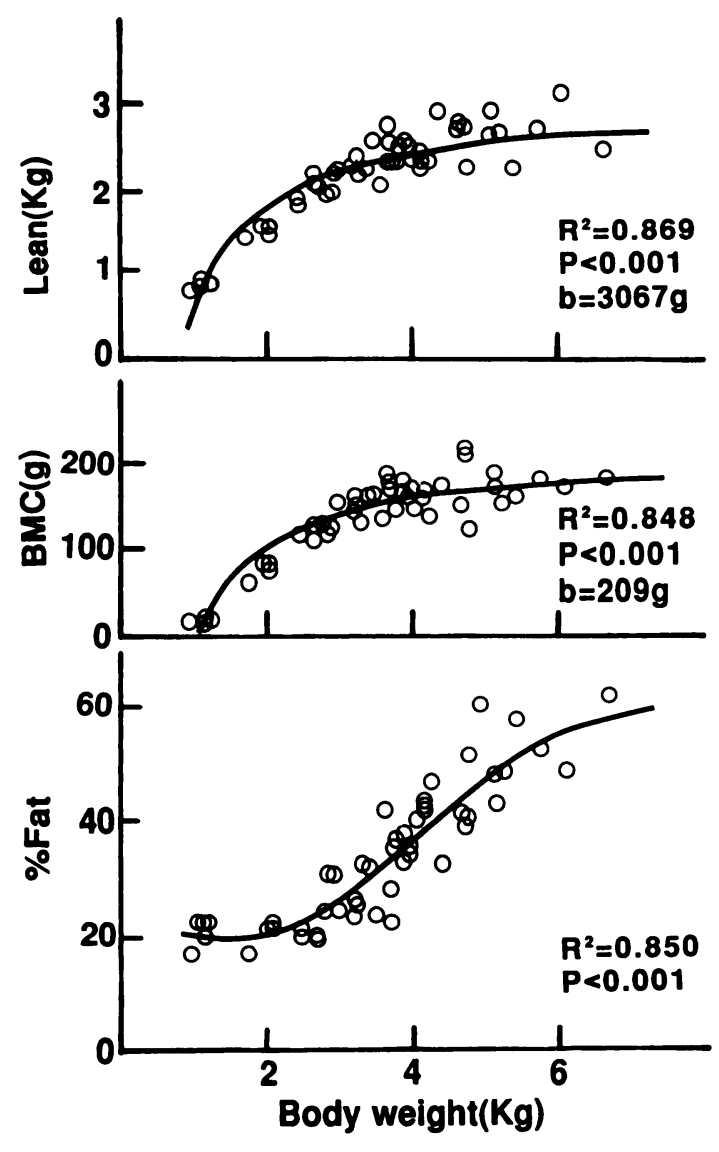

Fig. 4. The relationships between body weight and lean mass (upper panel), BMC (middle panel) and \%fat $(100 \times$ fat mass/soft tissue mass, lower panel $)$ in female cynomolgus monkeys. Coefficient of determination $\left(R^{2}\right)$, statistically significance $(p)$ and upper limiting value (b) calculated are indicated in the figure.

(Lean) および体重とBMC との間には, 関数式 $\mathrm{y}=\mathrm{a} / \mathrm{x}+\mathrm{b}$ が最もよく適合した。(Fig. 4，上段 および中段)。ただし， $\mathrm{y}$ は測定值， $\mathrm{x}$ は体重，そし て a，bは式を適合させるためのパラメータである。 適合の程度を示す決定係数 $\left(\mathrm{R}^{2}\right)$ の值は，それぞれ $0.869,0.848$ であり，0.1\%の有意水準で良好な適合 性が認められた。そしてそれぞれの式から算出された 上限值は，Lean で3.067kg，BMCで209g であった。 BMC およびLeanは，体重が $4 \mathrm{~kg}$ を越えるころか らプラトーに達する傾向が認められたものの, \% Fat は，体重が $3.5 \mathrm{~kg}$ 以下では20 30\%程度しかなかった ものが, 体重が $3.5 \mathrm{~kg}$ を越えたものでは，その割合を
顕著に増して， $7 \mathrm{~kg}$ の動物では $60 \%$ にも達した。体 重と\% Fat との関係には，ゴンペルツ式や，ロジス テック式も適合させたが, 最も適合したのは三次関数 $\mathrm{y}=\mathrm{ax}^{3}+\mathrm{bx}^{2}+\mathrm{cx}+\mathrm{d}$ であった（Fig. 4，下段）。 但し, $\mathrm{y}$ は\% Fat 值， $\mathrm{x}$ は体重， a ， b ，c， d は 式を適合させるためのパラメータである。 $\mathrm{R}^{2}$ 值は 0.850 であり，統計学的に有意な回帰が認められた $(\mathrm{P}<0.001)$ 。

Lean および BMC に上限值があるとすれば，それ ら上限値の和を越える体重の增加は, 体脂肪量の增加 に由来することになり, 肥満の程度を示しているもの と判断される。しかし, 脂肪の絶対量は, 逆に肥満し ていなくとも体重の大きさに左右されるものである。 そこで，\%Fat を指標とすることにした。また，適 合させた式の特性上，体重を無限に増加させたところ に、上限傎が設定されることになるがこの做を雌カニク イザルの成熟値とみなすことは困難である。そこで, $90 \%$ 值を採用すると，Lean は $2.76 \mathrm{~kg}$, BMCは0.19 $\mathrm{kg}$ である。Lean が $2.76 \mathrm{~kg}$, BMC が0.19kgの個体 が30\% Fatであるとすると，脂肪量は $1.2 \mathrm{~kg}$ であ り，算出された体重は $4.1 \mathrm{~kg}$ となる。この值は Fig.4 下段にあてはめると，ほぼ妥当な位置を占める。他 方，50\% Fatであると仮定すると脂肪量はLean と同 量の $2.76 \mathrm{~kg}$ であり，体重は $5.7 \mathrm{~kg}$ と算出される。こ の值も, Fig. 4 下段でほほ妥当な位置を占める。以 上の計算にはいくつかの前提があるものの, 体重がお およそ $4 \mathrm{~kg}$ 以上の動物での增加分は, 脂肪の蓄積量 の増加に由来すると判断され，雌カニクイザルの肥満 を検出しているものと言えよう。\% Fatの值は雌力 ニクイザルの脂肪の過㮃な蓄積, すなわち肥満の検出 の指標として用いられる可能性を示すものである。今 後, 雌カニクイザルで肥満が始まる時期, あるいは肥 満と妊娠・分婏との関係等について詳細な検討をおこ なっていきたい。

以上のことから，DEXA を用い，測定条件をサル 用に改良することで，カニクイザルの骨量・軟部組織 量および\% Fat の測定が可能であること，\% Fatの 值を用いてカニクイザルの肥満度を測定することが可 能であると考えられる。

\section{要 約}

二波長 X線画像解析装置 (DEXA, DPX- $\alpha$, Lunar 社製）で小児用プログラムを用い全身モードの走査を 
行うことにより雌カニクイザルの骨量・軟部組織量 (赤身肉・脂肪量) の生体計測が可能であった。測定 の正確性は, ウシ赤身肉, ブ夕脂身および胁骨で構成 したダミーを測定することにより確認した。また，軟 部組織量に占める脂肪量の割合（\% Fat）が, 雌力二 クイザルの肥満の良好な指標となり得ることが明らか になった。

本研究をおこなうにあたって, 当センターへの DEXAの導入 に便宜を払っていただいた, 日本電子株式会社柴田安弘部長並 びに同輸入販売株式会社設楽 武主任に感謝いたします。また タミーの作成にあたって御援助いただいた株式会社ミートパビ リオンつくば店の皆様に深謝いたします。本原稿の作成には椎 名京子さんの御協力をいただきました。

\section{文献}

（1］冷岡昭雄・吉田高志・長 文昭・吉川泰弘 (1994). 実験動
物, 43, 235-241.

[2] Lands, L. C., Heigenhauser, G. J. F., Gordon, C., Jones, N. L., and Webber, C. E. (1991). J. Appl. Physiol., 71, 698-702.

[3] Pierson, R. N. Jr., Wang, J., Heymsfield, S. B., Russell-Aulet, M., Mazariegos, M., Tierner, M., Smith, R., Thornton, J. C., Kehayias, J., Weber, D. A., and Dilmanian, F. A. (1991). Am. J. Physiol., 261, E103-E108.

[4] 清水利行 - 小野孝浩 - 吉田高志 - 長 文昭 - 後藤信男 (1988)。実験動物, 37, 145-151.

[5] 清水利行 - 成田勇人 - 大久保文雄 - 吉田高志 - 長 文昭 吉川泰弘 (1994)。実験動物, 43, 173-180。

［6］清水利行・古田高志・長 文昭・後藤信男 (1991). 実験動 物, 40, 215-221.

[ 7 ] 吉田高志 (1990). 成長, 29, 75-118.

［8］吉田高志 - 後藤幸江・羽成光二・清水利行 - 中島雅子・長 文昭・本左重男 (1982)。成長, 21, 12-19.

［9］古田高志・大藤圭子・成田勇人・大久保文雄・長 文昭 吉川泰弘（1994）。実験動物，43，199-207。 